DOI https://doi.org/10.30929/2307-9770.2021.09.04.02

UDC UDC [37.01/.09/811.111+327.3]378(045)

\title{
Contemporary practices of foreign language preparation of future international relations specialists at universities
}

\author{
Vasylyshyna N.*
}

National Aviation University, Kyiv, Ukraine

\begin{abstract}
Received: 07.10 .2021
Accepted: 01.12 .2021

The article analyzes the changes taking place in Ukrainian education during the last five years, are compared with the processes taking place in Europe, and an attempt is made to identify the main trends in the development of domestic foreign language education in the near future, allowing us to: predict probable challenges and prepare for overcoming them; focus on the main areas; to formulate new tasks, review the content, and possibly approaches to methodological training foreign language teachers taking into account these trends. Special attention is paid to the training of specialists in the field international relations is due to the fact that the process intercultural communication is significantly complicated problems due to certain differences and differences in perception of the world around us native speakers of different languages and cultures, which often leads to misunderstanding of each other, and in some cases becomes the cause of undesirable situations. The purpose of the article is to analyze the peculiarities of the development of foreign language education in Ukraine, to investigate the tendencies of the influence of the European educational system on the development of foreign language education in our country. The article highlights the results of the study of trends in the development of foreign language education in Ukraine, them influence on the formation of methods of learning foreign languages in higher education, their effective used during foreign language training of future specialists in non-language specialties in modern times stage. Some aspects of the formation and development of foreign language education at different stages of it are analyzed formation in the context of the subject of research and their relevance in modern conditions of preparation for the future specialists in the humanities in higher educational institutions of Ukraine. The main directions are clarified development of trends in foreign language education through analysis of works and research of leading experts in the field. In the frame of the study, it was revealed that the concepts of "bilingualism", "plurilingualism", and "multilingualism" in the system of higher education in Ukraine have become the significant components of foreign language training of future specialists in a particular field. The research concluded that, at the present stage of Ukraine's entry into the European educational space foreign language education is an element of cultural interaction, that promotes the formation of interests in another mentality, increases motivation, and expands the scope of international cooperation. We see the conclusions and prospects for further research in this area in a more in-depth approach to creative development and finding new ways to improve efficiency of the educational process of students of the faculties of international relations in the light of the latest requirements of the Ministry of Education and Science of Ukraine for teaching foreign languages at a qualitatively new level.

Key words: modern higher education, future international relations professionals, foreign language training, trends, development of foreign language education, professional skills and capabilities, diversification in methods, information technologies.
\end{abstract}

\section{Сучасні практики іншомовної підготовки майбутніх фахівців міжнародних відносин в університетах}

\author{
Василишина Н. М. \\ Національний авіаційний університет, Київ, Україна
}

Анотація. У статті проаналізовано зміни, що відбуваються в українській освіті за останні п'ять років, порівняно
з процесами в Європі, і зроблено спробу визначити основні тенденції розвитку вітчизняної іншомовної освіти в
найближчому майбутньому, що дозволить нам: передбачити ймовірні проблеми та підготуватися до їх
подолання; зосередитися на основних напрямках; сформулювати нові завдання, переглянути зміст і,
можливо, підходи до методичної підготовки вчителів іноземної мови з урахуванням цих тенденцій. Особлива

Corresponding Author: Vasylyshyna Nataliia Maksymivna, Тел. (068)59-30-727. E-mail: filologyN@gmail.com National aviation university, Metrologichna Street 6, flat 103, Kyiv, Ukraine, 03143.

Відповідальний автор: Василишина Наталія Максимівна, Тел. (068)59-30-727. E-mail: filologyN@gmail.com Національний авіаційний університет, вул. Метрологічна 6, кв.103, Київ, 03143. 
увага до підготовки фахівців у галузі міжнародних відносин пов'язана з тим, що процес міжкультурної комунікації істотно ускладнюють проблеми, обумовлені певною розбіжністю і різночитаннями в сприйнятті навколишнього світу носіями різних мов і культур, що часто призводить до нерозуміння один одного, а в деяких випадках стає причиною небажаних ситуацій. Мета статті - проаналізувати особливості розвитку іншомовної освіти в Україні, дослідити тенденції впливу європейської освітньої системи на розвиток іноземної мови в нашій країні. У статті висвітлено результати дослідження тенденцій розвитку іншомовної мови в Україні, їх вплив на фрормування методів вивчення іноземних мов у вищих навчальних закладах, їх ефективне використання під час іншомовно-професійної підготовки майбутніх спеціалістів з немовних спеціальностей на етапі Нового часу. Проаналізовано деякі аспекти фрормування та розвитку іншомовної освіти на різних її етапах становлення в контексті предмета дослідження та їх актуальність у сучасних умовах підготовки майбутніх спеціалістів гуманітарних дисциплін у вищих навчальних закладах України. Основними напрямками $€$ огляд тенденцій в освіті іноземних мов шляхом аналізу робіт та досліджень провідних фахівців у цій галузі. В рамках дослідження було виявлено, що поняття "двомовність", "багатомовність" у системі вищої освіти України стали вагомими складовими іншомовно-професійної підготовки майбутніх фрахівців у певній галузі . У дослідженні ми прийшли до висновку, що на сучасному етапі входження України до європейського освітнього простору іншомовна освіта сучасного фахівця $€$ елементом культурної взаємодії, що сприяє формуванню інтересів в іншому менталітеті, підвищує мотивацію та розширює сферу міжнародного співробітництва. Висновки і перспективи подальших досліджень у даному напрямку бачимо в більш поглибленому підході до творчої розробці та пошуку нових шляхів підвищення ефективності навчального процесу студентів факультетів міжнародних відносин у світлі останніх вимог Міністерства освіти і науки України щодо викладання іноземних мов на якісно новому рівні.

Ключові слова: сучасна вища освіта, майбутні фахівці міжнародних відносин, навчання іноземним мовам, тенденції, розвиток іншомовної освіти, професійні навички та можливості, урізноманітнення методів, інформаційні технології.

\title{
Современные практики иноязычной подготовки будущих специалистов международных отношений в университетах
}

\section{Василишина Н. М.}

\author{
Национальный авиационный университет, Киев, Украина
}

\begin{abstract}
Аннотация. В статье проанализированы изменения, происходящие в украинском образовании за последние пять лет, по сравнению с процессами в Европе, и сделана попытка определить основные тенденции развития отечественной иноязычного образования в ближайшем будущем, что позволит нам: предусмотреть возможные проблемы и подготовиться к их преодолению; сосредоточиться на основных направлениях; сформулировать новые задачи, пересмотреть содержание и, возможно, подходы к методической подготовки учителей иностранного языка с учетом этих тенденций. Особое внимание к подготовке специалистов в области международных отношений связана с тем, что процесс межкультурной коммуникации существенно усложняют проблемы, обусловлены определенной расхождением и разночтениями в восприятии окружающего мира носителями разных языков и культур, что часто приводит к непониманию друг друга, а в некоторых случаях становится причиной нежелательных ситуаций. Цель статьи - проанализировать особенности развития иноязычного образования в Украине, исследовать тенденции влияния европейской образовательной системы на развитие иностранного языка в нашей стране. В статье отражены результаты исследования тенденций развития иноязычной речи в Украину, их влияние на формирование методов изучения иностранных языков в высших учебных заведениях, их эфффективное использование во время иноязычной профессиональной подготовки будущих специалистов по неязыковых специальностей на этапе Нового времени. Проанализированы некоторые аспекты формирования и развития иноязычного образования на разных ее этапах становления в контексте предмета исследования и их актуальность в современных условиях подготовки будущих специалистов гуманитарных дисциплин в высших учебных заведениях Украины. Основными направлениями являются обзор тенденций в образовании иностранных языков путем анализа работ и исследований ведущих специалистов в этой области. В рамках исследования было выявлено, что понятие "двуязычие", "многоязычие" в системе высшего образования Украины стали весомыми составляющими иноязычной профессиональной подготовки будущих специалистов в определенной области. В исследовании мы пришли к выводу, что на современном этапе вхождения Украины в европейское образовательное пространство иноязычная образование современного специалиста является элементом культурного взаимодействия, что способствует формированию интересов в другом менталитете, повышает мотивацию и расширяет сфреру международного сотрудничества. Выводы и перспективы дальнейших исследований в данном направлении видим в более углубленном подходе к творческой разработке и поиска новых путей повышения эффективности учебного процесса студентов факультетов международных отношений в свете последних требований Министерства образования и науки Украины по преподаванию иностранных языков на качественно новом уровне.
\end{abstract}


Ключевые слова: современная высшее образование, будущие специалисты международных отношений, обучение иностранным языкам, тенденции, развитие иноязычного образования, профессиональные навыки и возможности, разнообразие методов, информационные технологии.

\section{Introduction}

An urgent problem formation and improvement of students international relations faculties of higher educational institutions of sustainable practical skills effective foreign language professional intercultural communication is somewhat beyond pure linguistics and classical methods of teaching a foreign language, deployed at the junction of a number related humanities disciplines and is considered as multifaceted, multilevel, cross-disciplinary and meeting the requirements of the time.

For Ukraine, European integration is joining a single family of European nations, returning to European political and cultural traditions. European integration is becoming a key part of Ukraine's opening to the world, the transition to an open democratic society. The main direction of cultural-educational and scientific-technical integration is to determine the implementation of European norms and standards in education, science and technology, dissemination of own cultural and scientific-technical achievements in the EU. They cover the fields of secondary and higher education, retraining, culture and science, art, engineering and technology [1; 4].

The integration process in the relevant areas is the implementation of European norms and standards in education, science and technology, the dissemination of their own cultural and scientific and technical achievements in the EU. The need to reform the system of higher education in Ukraine, improving its quality is due to globalization and the need to create positive conditions for individual human development $[4 ; 9]$.

The main purpose of state policy in the field of education is to create conditions for the development of personality and creative self-realization of every citizen of Ukraine, updating the content of education and organization educational process in accordance with democratic values, market principles of the economy, modern scientific and technical achievements. The priority directions of the state policy on the development of education are: personal orientation of higher education; formation of national and universal values; creating equal opportunities for citizens to obtain higher education; constant improvement of the quality of education, updating its content and forms of organization of the educational process; introduction of educational innovations and information technologies; formation in the education system of normative-legal and organizational-economic mechanisms of attraction and use of extra-budgetary funds; raising the social status and professionalism of educators, strengthening their state and public support; development of education as an open state and social system (exams, programs, learning process, education); integration of Ukrainian higher education into the world educational space $[1 ; 7]$.

According to the general civilizational tendencies of development of education in Ukraine it is provided: transition to a dynamic step-by-step system of training (provides growth of educational and qualification level, professional mobility); formation of a network of universities that would meet the interests of the individual, his needs and at the same time the state; raising the educational and cultural level of society; raising higher education in Ukraine to the level of higher education in developed countries [2; 3].

Moreover, it is necessary to transform the quantitative indicators of educational services into qualitative ones on the basis of: the national idea of higher education, the content of which is based on the multiplication of national educational traditions; the development of higher education is subject to the laws of a market economy; the development of higher education is considered in the context of trends in world education systems $[1 ; 4]$.

\section{Materials and Methods}

Methodological base comprised: analysis of psychological, pedagogical and educational literature on the research topic; study and generalization domestic and foreign pedagogical experience in applying the system methodological training; collection of information on the learning process and application of distance learning system. Generalization and prognostic methods for formulating conclusions.

E. Mahmutov in the book "Problems of learning: Basic issues of theory" points out that "the essence of the problem presentation of knowledge by the teacher is that instead of transferring ready-made provisions (rules, laws) of science, the teacher reports the actual material, gives its description against the background 
problem situations, constantly encourages students to partial or complete independent cognitive activity with the establishment and solution of educational problems.

The problem of the development of language and, in particular, foreign language education in Ukraine has been studied by a number of scholars, among whom: N. Ivanytska, L. Karpets [5].

The foreign language problems were studied by many scientists, in particular: D. Bagliy, O. Bigich, N. Borisov, N. Vereshchagin, V. Vykhrushch, I. Georgian, A. Dolapchi, V. Karpova, A. Kirda, A. Krasulya, T. Litkova, O. Myrolyubov, O. Moskalska, I. Rakhmanov, G. Horny [8; 10; 12].

J. Dewey offers his concept of problem-based learning. It includes five stages of problem solving: the appearance of a sense of complexity of the problem; its detection and determination: presentation of a possible solution; identification by inferences of probable solutions; further observations and experiments that lead to the acceptance or rejection of the accepted assumption, ie to the conclusion that has a positive or negative judgment.

Wallace proposed a solution to the problem through four main phases: 1) personality preparation and Attempts to solve the problem; 2) incubation - the period "Maturation" of the decision; 3) instantaneous flash of the idea-decision; 4) verification - checking the effectiveness of the decision and clarification of a new idea.

Summarizing the theories of problem-based learning, Yu. Kozeletsky proposes to consider the process of solving the problem by students through three phases: creating a problem situation.

In the 1950s, the American psychologist Skinner proposed the concept of programmed learning, the main element of which was the program as an ordered sequence of recommendations (tasks) transmitted using a didactic machine or programmable manual. Depending on the nature of the training and the expected answers, there are linear, branched and mixed programs [9].

The driving force behind the search for new learning technologies has been and is the belief that the ideas of individualization of learning must be implemented. Research of many scientists - B. Ananieva, P. Blonsky, L. Vygotsky and others. show that the individualization of learning determines the organization of the educational process, in which the choice of methods, techniques, pace of learning, taking into account the individual characteristics of learners, and the level of their ability to learn [12].

After analyzing the theoretical and empirical material of pedagogical science and practice of the $\mathrm{XX}$ century, R. Tyler identified the following characteristics of individual learning:

-the student works at an individual pace at a time convenient to him;

-the learner chooses from the proposed learning tools those that he considers most effective;

-the learner receives individual help in case of difficulties;

-the learner reaches different levels of knowledge about the content of learning;

-the learning process is organized in such a way that creates a favorable microclimate [14; 17].

Advanced pedagogical experience plays an extremely important role in the modernization of education, improvement of the educational process, improving the quality of education and upbringing of schoolchildren. I. Krivonos notes that the advanced pedagogical experience is formed on the basis of pedagogical experience as a whole as an independent functional subsystem with its own set of effective methods and techniques of teaching and education, the rules of their application and evaluation [14].

Advanced pedagogical experience, according to N. Moiseyuk, is the activity of a teacher that ensures sustainable efficiency of the educational process through the use of original forms, methods, techniques, teaching and education tools, new systems of teaching and education or already known forms, methods, techniques, means of work on the basis of their improvement [10].

The basis of the innovative experience of the physics teacher $V$. Shatalov is the method of submitting new material in large blocks, which causes a significant reduction in the time of study of individual subjects. The presentation of the material in large blocks (topic, section), the teacher notes, allows you to better understand it, to understand the logical relationships where previously there were only individual theorems, rules, paragraphs. The student is given the opportunity to see the whole way, not part of it [12; 17].

The use of computer tools enhances the effectiveness of learning through: a wide range of imaging capabilities; significant expansion of the range of tasks; enrichment of the subject content of tasks by studying real industrial and social situations; increasing the level of problem tasks; updating the content of tasks thanks to game components, special rules of operation of artificial objects; emergence of fundamentally new tasks, in particular for the construction of expert systems for educational purposes [14; 16]. 
Computerization of education causes changes in the ratio of different organizational forms of educational activities, in particular, increases the share of independent, individual and group work; the volume of practical and laboratory works, first of all, search and research character expands, the role and value of outof-class lessons increases [15].

The name of M. Guzyk is well-known in the innovative movement, who considers the presentation of new material "in large portions" to be the main principle of the education system. The planning of each topic includes lessons-lectures, lessons-seminars, lessons of generalization and systematization of knowledge, lessons of protection of creative tasks, lessons-workshops [17].

Formation of hypotheses to solve the problem. Today the education system in Ukraine focused on entering the single world information and educational space. This process is accompanied by radical changes and adjustments as in the pedagogical theory and practice, and in the implementation of the educational process. Particular attention is paid to the development of foreign language education, in parallel with improving the system of native language education, studying the priorities of language policy Ukraine and the world, the study of philosophical and axiological principles of native and multilingual education, the formation of intercultural tolerance by means of native and foreign languages development of linguistic and communicative competence of different categories of the population, and study pedagogical and psychological principles of formation of communicatively competent personality [2; 7].

Thus, the problem of foreign language education is quite relevant for educational and scientific space of Ukraine, the problem of peculiarities of development remains important for studying foreign language education in Ukraine, the study of which will help to better understand the role of new ones technologies in the practice of foreign language training of future professionals as a necessary component and conditions of cognitive, intellectual, creative and moral development of personality and competitive capable specialist [8; 10; 12].

The purpose of the article is to analyze the peculiarities of the development of foreign language education in Ukraine, to investigate the tendencies of the influence of the European educational system on the development of foreign language education in our country.

\section{Results}

State National Program "Education" (Ukraine in the XXI century) defines the strategy of Ukraine in the field of education, aimed at the development of the national education system, the formation of a creative personality. The purpose of the program is to bring Ukraine's education to the level of developed countries by radically reforming its conceptual, structural and organizational elements $[2 ; 5 ; 6]$.

The main, fundamental principle of teaching and education The program called the principle of humanism, which requires: a) compliance of educational results with the capabilities and natural inclinations of the child, dialogical communication of equal participants in the educational process; state of mental and physical health, as an integral indicator of the effectiveness of education, along with the level of knowledge and education; b) humanization of education, significant changes in its content, increasing the share of disciplines of anthropological nature, strengthening the humanistic orientation of natural, mathematical and vocational education. The second strategic direction of the program was to improve the skills of personnel [5; 7].

All in all, the globalization and internationalization of society was small significant influence on the development of modern foreign language education has emerged the need to modernize it and improve the content of national school curricula in foreign languages for primary, secondary and high school, taking into account linguistic and psychological basics of teaching foreign languages and socio-cultural concepts mastering them [11].

As we can see, the trends in the development of foreign language education in Ukraine completely coincide with European. Since significant investments in education are expected in Europe by 2020, this is inspires hope that similar changes will take place in Ukraine in the near future. Each of the described trends in the development of foreign language education in Ukraine deserves more detail study, which are promising areas for further study of the problem [8].

It should be noted that the role of the English language in higher education in Ukraine has changed significantly in recent years, especially after the adoption of the law "On Higher Education", because in it emphasizes the strengthening of international cooperation of higher education institutions; their participation in 
programs bilateral and multilateral interstate and interuniversity student exchange, graduate students, doctoral students, pedagogical, scientific-pedagogical and scientific workers; conducting research; organization of international conferences; participation in international educational and scientific TEMPUS and Erasmus programs; joint publishing activities [8; 10].

This requires the teaching staff to own not domestic, but academic and scientific, professionally oriented in English, which is transformed from a language of communication into a language of professional use and international cooperation. Professional communication takes place in various formats and requires high degree of mutual understanding, high technical competence of specialists, use various strategies, techniques and technologies. Therefore, modern foreign language teachers should not be taught only types of foreign language speech activities and methods of their teaching in different educational institutions, but also editing, using software, computer graphics, the Internet, mobile technologies [11; 13].

Formation of foreign language communicative competence is the most important aspect of forming students' readiness for intercultural communication. Professional communicative competence, implemented in a foreign language communication, is defined as the ability to quickly and efficiently solve communicative problems in certain communicative situations. In terms of business communication, foreign language communicative competence can be defined as the ability to solve business problems to achieve a certain result in the context of a different business mentality and general culture [17, p. 81].

Recently, postgraduate teaching of foreign languages has begun to develop in Ukraine workplaces taking into account the specifics of professional activities of specialists. Such training has become be in demand because it provides the appropriate level of foreign language competence for effective activity in the conditions of the international market. Methods of teaching a foreign language for professionals are mainly teachers of non-language universities, language courses and individual foreign language teachers who work directly at the customer's workplace. There are still too few qualified specialists in this technique. In Ukraine, they are prepared only by a few universities, though scientists are already working hard to develop its theoretical foundations [15; 16].

In recent years, the concept of "bilingualism", "plurilingualism", and "Multilingualism" in the system of higher education in Ukraine as one of the components foreign language training of future specialists in a particular field, which significantly expands the scope interaction and competitiveness not only of future specialists, but also of higher ones educational institutions of the country [13; 17].

The purpose of language education has changed significantly at the present stage. Now it is perceived not simply as an achievement of mastery in one, or even several languages, implies possession of certain skills and abilities, and the possession of all becomes a necessity linguistic abilities to achieve a certain goal and objectives [15; 16].

So, another link in this system is the study of such typical situations in which future professionals in the field of international relations will often communicate professionally with the bearers of that or other culture. Focusing on the future professional activity of specialists in international relations, teachers should strive as much as possible to involve students in active participation in communicatively oriented activities: to involve them in analytical, constructive and game situations with representatives of other cultures and speakers of relevant languages [6, p. 44].

Thanks to modern technologies there are plenty of various online platforms that make English teaching process more interesting and effective. In our research we are going to present some of them.

The online platform for learning English has a number of advantages:

Mobility. All students need to learn English is a computer, a camera, a microphone and internet access. Everyone can organize their learning space independently. An online English school is available to people from all over the world. Representatives of different countries can study in one group and this makes learning more interesting, because you hear the pronunciation and accents of different people and learn to understand them.

Systematic. Learning should be systematic, because English must be practiced every day. Learning English online is available to anyone. Groups are divided according to the level of knowledge, as well as age, so there is a lot of interactivity in the classes, which helps to develop teamwork skills and demonstrate leadership qualities.

Interactivity. Modern technologies greatly facilitate the process of organizing learning, so the teacher 
has the opportunity to show their students interesting video and audio materials.

Accessibility. English is available online because all the materials you have are publicly available. The information is updated quickly and you can always follow the new materials and tasks.

Ease of use. The online platform can be used by children and adults. Convenient interface and clear sections do not cause unnecessary questions.

Control. English online involves all assignments given by the teacher, including homework. In the English-speaking community, we the students don't do a lot of homework, but they do and need to be done. Also, in each lesson, we spend about $30 \%$ of our time reviewing the material to understand how much students have memorized previous topics.

British Council of Ukraine. The British Council Learn English is a resource for learning English from the British Councils, the UK government's department for the dissemination of British culture. On the site you can learn grammar, vocabulary, improve writing and pronunciation skills.

Many courses, online conferences, information on university and professional exams, IELTS, artistic and cultural events, study in the UK. The British Council in Ukraine offers a number of free online materials and applications. In courses from the British Council, English is taught not only from the point of view of grammar, but in the socio-cultural plane. So here you can find courses Exploring English: language and culture, Understanding language: teaching and learning, How to succeed in the global labor market and more.

Udemy. The Udemy learning platform has in its arsenal many paid (from \$20) and free English language courses. They all differ in duration, subject matter, load, level of training required by the listener, etc. Unlike other distance learning platforms, for which courses are created under university programs, Udemy provides its platform to specialists and experts in various fields to create relevant courses. According to the developers, this gives more chances to gain practical skills, not just theoretical knowledge.

edX. Free education from the world's top universities. 2121 courses in English in all kinds of specialties: business, law, medicine, history, culture, environment, music, literature, linguistics, mathematics, physics, sociology, philosophy and much, much more.

Coursera presents many courses in various specialties, which can be taken free of charge, and only a certificate can be paid if necessary. Learn how to professionally sort garbage, write lyrics for songs, take excursions to museums.

But that's not all! Here you can also get real online education in the field of business, engineering, computer and other sciences from American, British and French universities.

Duolingo. One of the most popular online English courses that you can take using your smartphone. Today the application has over 120 million users. It has a pretty nice interface, detailed lessons, and all kinds of exercises to help you improve your pronunciation. This platform for online learning of the English language for each lesson is charged game currency, spending which you can purchase various bonuses. Also, the advantages of the application include reminders and notifications [15].

Easy Ten. A program for taking online English courses, thanks to which you can replenish your vocabulary daily by learning ten new words. Even in lite mode, you can learn 170 words in a week. And for all this, 20 minutes a day is quite enough. The app has competent voice acting, over 22,000 English words on various topics, pronunciation trainers, as well as the ability to track your progress and receive rewards that increase motivation. If necessary, you can use the search for words divided by thematic lists $[9 ; 13]$.

Fluent You. An application that allows you to take online English courses with maximum efficiency. Developers actively use various media content, which is the most effective way to learn. Here you can watch music videos, news, popular talk shows, interesting dialogues, commercials and much more. The app independently tracks all the words learned and recommends videos and tasks based on them [12].

Lingua Leo. One of the most effective applications for taking English courses online in a smartphone. With it, you can learn new words, learn to write in English, parse lyrics, watch videos with subtitles, and so on. This is a whole system that independently determines the strengths and weaknesses of each of the students. The features of the application are to get meatballs, which are given when completing tasks and with which you need to feed Leo the lion cub every day [16].

engVID. Site with video lessons for learning English, divided by thematic study. Those who want to take the IELTS or TOEFL international exam can take advantage of special video lectures to prepare [11].

Memrise is an original platform for learning foreign languages using a card system. Content can also be 
created by the users themselves. In 2017, the app won the Best Play of the Year category from the Google Play Awards [14].

TED is an organization dedicated to motivational cognitive lectures in English. TED talks with Ukrainian subtitles. Lectures at TED conferences on "ideas worth spreading" initially focused on technology, entertainment and design. But now you can find speeches on all aspects of life on the site: success, health, culture, art, education, business, global issues, the future. By watching videos from TED conferences, you not only learn to listen to stories, but also absorb interesting information that inspires and makes you think. It can be great for viewers with existing English knowledge who want to improve their hearing skills. Subtitles are available on the site [13].

Facebook. This social network is one of the most powerful tools for learning live English. The fact is that some bloggers, artists, politicians write their posts in both Ukrainian and English. Thus, texts in both languages about our present can be compared with each other, highlight and memorize certain idioms, learn to use words and phrases in sentences [13; 14].

Loyal books. A library of free e-books and audiobooks in different languages. An effective way to improve your vocabulary [13].

$B B C$ Learning English is a large branch of the BBC dedicated to the study of the English language. Training courses for different levels are available on the site. Some of the courses are divided into topics: English at university, at work, in the news. BBC video tutorials are just fresh air on learning both modern and traditional English. News service linguists will acquaint readers and viewers with regular expressions, parse and explain news headlines, highlight useful words, help understand thematic vocabulary, and more. Short videos (average duration - about 4 minutes), do not overload, but at the same time are very informative [13; 14].

So, students' smartphones are not just social networks, work and games, but also huge opportunities for improving new knowledge. Now online English courses are always in your pocket.

\section{Discussion}

Indeed, a modern English learning has many advantages, among them: freedom and flexibility, individuality, mobility, independent choice of pace training, attracting more people of different ages, is simple formation of virtual communities, which allows discussion between teachers of certain problems, solving common problems, sharing experiences or information. [3; 16].

Theoretical and practical aspects of IT and modern English learning have been considered in studies by both foreign and domestic scientists: J. Adams [2], F. Bodendorf [3], H. Dichanz [4], G. Hoppe [6], J. Kettunen [8], A. Andreeva [1], V. Vashchenko [3], K. Kolos [6], V. Kukleva [8].

Nevertheles, along with a plenty of pluses there are some sufficient disadvantages of technology-based learning, that include: lack direct face-to-face communication between students and teacher, loss of emotional coloring of the submitted material, difficulties in creating a creative atmosphere group of students, lack of hardware and software [11; 14].

Recent research in the field of interactive technology confirms that the potential of computer learning can be the greatest effectively used in the study of foreign languages, which includes discussion, comprehension of the material and coordinated collective activity.

But, one of the promising areas of work in the distance learning system in teaching foreign languages has an integrated approach to solving the main tasks that combine in this system: a set of technologies with high didactic potential and telecommunication technology; computer training of foreigner languages, multimedia technology and methods of intensive foreign language teaching [8; 9].

Moreover, it is very important in the process of IT learning to have constant reliable access to the latest learning technologies and the Internet for both teachers and educators. Technical failures, ignorance of the latest technologies training and inability to work with technical equipment, in particular computer, can cause stress and frustration in mastering educational material, because it is with the help of computers and Internet networks, students transfer their completed tasks, looking for the necessary information for a thorough study of the curriculum discipline. For example, online courses require a computer with Internet access.

For a English course with materials on CD or DVD you must have a media player. Currently, not all institutions are technically prepared for IT learning, so lectures and seminars are held using Office 365, 
Google Classroom, and the level of quality of knowledge, skills and abilities is assessed by using text tests, project presentations and messages from research is conducted through accessible social networks, in particular Moodle, Zoom, Skype, Viber, Telegram Messenger [11;12].

Lack of direct bilateral interaction that characterizes many IT education programs, contradicts the goals of teaching foreign language. However, using this interaction, remote technologies can maintain the integrity of foreign language teaching. Educational strategies that encourage student-teacher dialogue and student autonomy in distance learning situations, should be included in the learning.

We must admit, that to learn a foreign language using multimedia technologies, students must be independent and use new strategies. Because language learning in the traditional way usually takes place in person communication, and distance learning via Internet communication is a slightly different system without the participation of live contact. The Internet helps people communicate with native speakers via chats and email. Actually, students are exposed to a contextual environment using the Internet.

Through the use of the Internet, students can strengthen their own communication skills, get acquainted with different cultures and strengthen their own required skills such as listening, speaking, reading and writing. During Learning online anxiety is reduced and responses are quickly transmitted to students become more confident. Teachers are trying to integrate the Internet with their own learning materials and learning styles to create meaningful learning environment. Emails and chats that are carried through The Internet is an important part of communication between students and teachers, and also improve students' writing skills in language learning. But in e-learning the emphasis should be made on accumulation and use of knowledge and a special curriculum must be created that will be relevant to the abilities of students. [12; 13].

\section{Conclusion}

Thus, as a result of the analysis of changes that have taken place in the system of higher education since the time of receipt independence of the Ukrainian state, and their comparison with the processes observed in Europe, it can be concluded that the main trends in the development of foreign language education in Ukraine and Europe coincide.

Although European and somewhat ahead, but comparing the rapid pace of change that observed over the past five years in our country, we can predict the likely challenges that await us in the near future, and prepare in advance to overcome them, focus on main directions. We have time to formulate new tasks, review the content, and possibly approaches to methodical training of foreign language teachers taking into account these tendencies.

Modern IT learning impresses more people for education, in particular higher education, but there are a number of shortcomings it is worth paying attention to eliminate them and find a compromise for successful study of the discipline remotely.

We were able to highlight such shortcomings of the distance learning system, namely: limitations direct communication of students with teachers, lack direct access of students to the teacher, constant selfmotivation students, isolation of education, restrictions on available special courses training to master specialization, the need for constant reliable access to the latest learning technologies and the Internet networks, mandatory accreditation of distance learning programs, employment restrictions, no additional ones costs, restrictions on improving oral skills student communication.

The study does not cover all aspects of the problem, therefore further scientific interest will be the study and analysis of European experience in the development and formation of foreign language education, improving the methodology of foreign language training of specialists in certain fields and certain educational levels of higher education institutions of Ukraine and Europe, determining trends in the development of foreign language education in different age categories, studying the features of the phenomena of "plurilingualism" and "multilingualism" in process of foreign language training of future specialists in the conditions of higher educational institutions Europe and Ukraine.

\section{References}

1. Common European framework of reference for languages: learning, teaching, assessment. Language Policy Unit, Strasbourg. URL: https://www.coe.int/t/dg4/linguistic/Source/Framework_EN.pdf (accessed 09.09.2021). 
2. Debande, O. (2004). ICTs and the development of eLearning in Europe: The role of the public and private sectors. European Journal of Education, 39(2), 191-208.

3. Douglas, H. (2007). Teaching Principles, An Interactive Approach to Language Pedagogy. 569.

4. Garrison, R., Kanuka, H. (2004). Blended learning: Uncovering its transformative potential in higher education. The Internet and Higher Education, 7(2), 95-105.

5. Harasim, L., Hiltz, S., Tells, L., Turoff, M. (1995). Learning Networks: a Field Guide to Teaching and Learning on line. MIT Press, Cambridge MA, 145.

6. Humboldt, W. (1985). Language and cultural philosophy. Progress, Moscow, USSR, 450

7. Henning, J. (2008). The Art of Discussion-Based Teaching: Opening Up Conversation in the Classroom. Routledge, New York, 56-78.

8. Hughes, R. (2011). Teaching and Researching: Speaking (Applied Linguistics in Action). Pearson Education Limited,

9. Kozma, R. B. (1991). Learning with media. Review of Educational Research, 61(2), 179-211.

10. Kulik, C. L. C., Kulik, J. A. (1991). Effectiveness of computer-based instruction: An updated analysis. Computers in Human Behavior, 7(1-2), 75-94.

11. Kruse, K. (2015). The Benefits and Drawbacks of e-Learning. URL: http://www.corebiztechnology.com/software_article_elearning_d.htm (accessed 05.03.2015).

12. Simpson, O. (2012). Supporting Students for Success in Online and Distance Education. Routledge, New York and London, 296.

13. Legner, C., Eymann, T., Hess, T., Matt, C., Böhmann, T., Drews, P., et al. (2017). Digitalization: Opportunity and challenge for the business and information systems engineering community. Business \& Information Systems Engineering, 59(4), 301-308.

14. Littlewood, W. (1991). Communicative Language Teaching. CUP, Cambridge, 34-56.

15. May, S., Nancy H. (2008). Encyclopedia of Language and Education. SpringerScience\&BusinessMedia, LLC, vol. 1, 437.

16. Moodie, G. (2002). Identifying Vocational Education and Training. Journal of Vocational Education and Training, 54(2), 266-289.

17. Vasylyshyna, N. (2014). English in Context. PRINT LINE, Kyiv, Ukraine, 196.

18. Yıldırım, A. (2001). A Qualitative Assessment of the Curriculum Development Process at Secondary Vocational Schools in Turkey. Journal of Career and Technical Education, 1, 57-59.

19. Zagonari, E. (2009). Balancing tourism education and training: International Journal of Hospitality Management. International Journal of Hospitality Management, 28, 2-9.

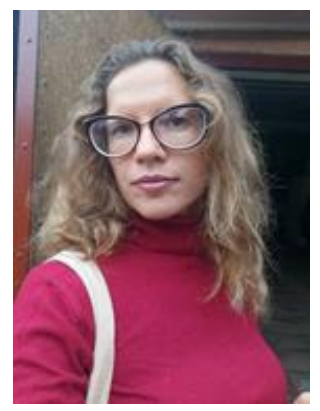

\section{Василишина Наталія Максимівна}

Д-р.пед.наук, доцент, доцент кафредри іноземних мов,

Факультет міжнародних відносин,

Національний авіаційний університет,

вул. Метрологічна 6, кв.103, Київ, 03143.

Тел. (068)59-30-727. E-mail: filologyN@gmail.com

Vasylyshyna Nataliia Maksymivna,

D.Sc. in Pedagogics, Associate Professor, Associate Professor of Foreign Language Department,

Faculty of International Relations,

National Aviation University,

Metrologichna Street 6, flat 103, Kyiv, Ukraine, 03143.

Тел. (068)59-30-727. E-mail: filologyN@gmail.com

ORCID: 0000-0002-0003-9998

Researcher ID: H-1189-2019

\section{Citation (APA):}

Vasylyshyna, N. (2021). Contemporary practices of foreign language preparation of future international relations specialists at universities. Engineering and Educational Technologies, 9 (4), 25-34. doi: https://doi.org/10.30929/2307-9770.2021.09.04.02

\section{Цитування (ДСТУ 8302:2015):}

Василишина Н. М. Сучасні практики іншомовної підготовки майбутніх фахівців міжнародних відносин в університетах / Інженерні та освітні технології. 2021. Т. 9. № 4. С. 25-34. doi: https://doi.org/10.30929/2307-9770.2021.09.04.02

Обсяг статmi: $\quad$ сторінок - 10 ; умовних друк. аркушів - 1,448. 